\title{
English Undergraduate Students' Expectation of Online Learning for English Speaking Skill
}

\author{
Ayunida Gustriani ${ }^{*}$ and Hamzah ${ }^{2}$ \\ ${ }^{12}$ English Department, FBS Universitas Negeri Padang, Padang, Sumatera Barat 25131, Indonesia, email \\ ${ }^{*}$ Corresponding author, email ayunidagustriani@gmail.com
}

\begin{abstract}
Due to the spreading of Covid-19, face-to-face learning has been changed to online learning. Online platforms and applications have been used to support English teaching and learning process like teaching English speaking skill. One of ways to make online learning successfull is through knowing students'satisfaction. The students will satisfy when their expectation can be achieved such as in the aspect of instructor, course content, learning style, interaction, technology, resources, etc. The research only focus on the expectation in terms of instructor, interaction, teaching learning style and learning platform. Thus, this paper aims to find out students' expectation of online learning for English speaking skill. In this preliminary research, the participant were 30 students who are taking Oracy in Academic Context course chosen by using simple random samping. The quantitative study is chosen as the research design. The questionnaire is used to collected the data and adapted from Paechter (2010) and Lemos (2012) and developed based on expectation and satisfaction theory from Bolliger and Martindale (2004). The formula proposed by Bungin (2006) was used to calculated the students' expectation of online learning for speaking skill. Based on the analysis, the percentage for instructor aspect is $54 \%$, for interaction aspect is $52 \%$, for learning style aspect is $52 \%$ Thus, it can be interpretd that the students who are taking Oracy in Academic Context course have positive expectation on the aspects instructor, interaction, teaching learning style and learning platform during online learning for English speaking skill.
\end{abstract}

Keywords : students' expectation, online learning, english speaking skill

\section{INTRODUCTION}

Due to the spreading of Covid-19 in Indoesia, the government made a regulation to education sytem which face-to-face learning need to be change to online learning. Therefore, the use of online learning has been used widely for all of education level in Indonesia started from primary, secondary until tertiary education. In tertiary education, the online learning was started from $17^{\text {th }}$ March 2020 until the end of even semester and continue to the odd semester in 2020. The student who enrolled in University had to follow online learning from home. Cavanaugh and Clark define online learning as kind of distance education which both the teacher and students are aparted by time and location [1]. They do not physically meet in real time situation of clasroom. Electronic (online or video-based learning) or nonelectronic (print-based individual learning) is form of distance education [1]. Online learning can be conducted synchronous, asynchronous or scheduled asynchronous [2]. So, online learning can be done whether through internet-based or print based. The learning can be conducted at the same or different time among teacher and students or set the time for learning in online platform but the teacher and student do not need to be online at the same time.

Several online applications have been used as learning platform such as Google Classroom, Google meet, Zoom, WhatsApp, Schoology, website e-learning made by the institution or universities itself and many other. Also use additional platform or social media like Youtube for submit the task or get video for learning material and Instagram for platform to submit the task. Thus, internet connection are really important during this kind of learning. It is because the use of internet is not only use for accessing the learning materials, but also for having interaction with the content material, with instructor, teacher or lecturer, and with other students. Also for getting support along the learning process in order to acquiring knowledge, building individual meaning, and developing from the learning experience [3].

Based on the observation that have been done in Oracy at Academic context course which learn speaking and listening, it found that the lecturer have already conducted fully online learning. The learning conducted through online or video-based learning that use online learning platfom like Zoom for video conferencing, 
Schoology for giving and submittng task, Instagram and Youtube for uploading the task also Youtube for source of getting listening and speaking material. The process of teaching and learning speaking and listening through Zoom give the students opportunity to speak actively and practice to use appropirate grammar and vocabulary. The students also gives much opportunities to practice their speaking and listening skill outside te course like making presentation or reviewing video. They also given the opportunity to see others friend's work, do evaluation and give comment.

Furthermore, learning listening and speaking usually expect the students to be profcient and eloquent in producing an utterance about the material they have listened. The student also expect to use appropriate grammar and vocabulary, use correct social and cultural ethics that relevant to the condition or environment [4]. While the listener listen material about to language the speech from various sources such as video, film, music. So the student can produce utterance by themself after listen to the material. Therefore, the instructor or lecturer can utilize technology to support teaching English speaking and listening skill. The use of technology like online learning media can be provide audio, video, text, animation, graphics, etc that are very useful for teaching speaking listening. Thus, the instructor can can achieve successfull and effectiveness of teaching learning speaking event hough through online application and platform during online learning.

Moreover, one of ways to know the successfull and effectiveness of online learning is through students satisfaction because it is become an indicator for evaluating the couse and determining the online learning program effectiveness [5] [6]. According to $\mathrm{Wu}$, Tennyson and Hsia, learner satisfaction refers to attitudes, perceptions and expectation of learners toward a specific learning mode [7]. It means students attitude and perception about whether they are being gratify or dissapoint to the online learning or online course that offered. Also whether students expectation are achieve during the online teaching and learning. So at the end of the semester, the lecturer can evaluate the online teaching and learning process through the result of students' satisfaction. The instructtor, teacher or lecturer can begin with finding out the students expectation of online learning that will use to assess students satisfaction because expectation and satisfaction are related [8].

Dealing with students expectation of online learning, there are several factor that affect it. Lemos argue these factors hold important role in online learning because they can be used as barometer of course design suitability and online learning circumstances appropriateness [9]. Boliger and
Martindale provide seven factor that contributed to students satisfaction of online learning that are instructor issue, communication or interaction, technology, course website, course management, interactivity and general information [10]. The paper only focus on instructor issue, communicationor interaction, lerning style and technology or learning platform. Firstly, the instructor is the main factor that influence students satisfaction because she/he the one who will be presenting the material and giving help, support, motivation and feedback to the students in distance. Second, communication is interaction between instructor and student and interaction between student to other students. Third, technology that used for learning must be able to accessed by the students, familiar with them and easy to use. Fourth, learning style that makes students active doing meaningful activities, can built their own knowledge, can cooperate with others student in learning [1].

Related to the students expectation of online learning, several researcher have been done the research about it. Lemos found the highest expectation of magister students for online course is resources which need to be provided simply, useful, varied, interested material and concurrently with graphics. While the most satisfy factor in online learning is curricular program (easiness of access content), faculty and instructor (proficiency of online teaching, teachers' approachability and be able to adapt with different students' learning style) [9]. While university students in Austria expect course aspect is important in elearning. The most predictor for success in learning is the students' achievement goals. While instructor proficiency and instructor advice, suggestion and support are the highest aspect for predict learning accomplishment and course satisfaction [11]. Furthermore, related to the satisfaction of online learning, Wei and Chou observe 356 undergraduate stundents of online course in Taiwan to find out online learning perception and whether online learning readiness influence students' performance and course satisfaction or not. They found that the students' computer readiness or internet self-efficacy for online learning affect their online learning perceptions and online discussion score, also affect to the course satisfaction [12]. While Cole, Shelley and Swartz found the highest factor that impact students satisfaction of online course in university level is convenience factor. Other factor are course structure involve clarity, the facility given by instructor with online instruction, communication and interaction with the instructor, course that appropriate with the student's learning style and satisfy with the Blackboard as the online learning platform [13]. Last but not least, Shaw, Tam, Hogle, 
Koch found students are satisfied with learning curriculum and interaction with inctructor while motivation and desire are key of successfull learning [14].

Thus, the students might expect different expectation such as in terms of resources, instructor proficiency in teaching online, learning style, learning platfrom, ect.

Also the same with satisfaction that influenced by many factors from the students itself, the instructor, course and technology that support online learning. So by knowing students expectation and satisfaction of online learning, the university, faculty, department and the instructor can pay attention to all of aspect of online learning such as learning platform, the clarity course content, convenience, resources, teacher competence in using technology, and many others that might become students expectation. They need to be prepare well in designing the course during online learning because it is different with traditional learning where there is face-toface interaction.

From the previous studies above, online learning still become important issue for research topic escpecially in this pademic era where learning conducting fully online. Students expectation is consider as important issue to be investigated because the students expectation can affect to the learning outcome and successful online learning and determine the quality of online learning. The students' expectation of online learning is hope to become the indicator to evaluate the online learning and fulfill students expectation. So the teacher, faculty and university can maximize the strengths and minimize the weaknessess in online learning.

\section{METHODS}

This is a quantitative research that try to find out the students' perception of online learning for English speaking skill. The perception is about student expectation. In this preliminary research, the participant were 30 undergradute English students who were taking Oracy in Academic Context course chosen by using simple random samping. The close-ended questionnaire which consist of 40 statements in form of Google Form was used to collected the data. the statements were based on a five-point Likert scale with response options begin from strongly agree, agree, neutral, disagree to strongly disagree. The questionnaire was adapted from Paechter and Lemos and developed based on expectation and satisfaction theory from Bolliger and Martindale. The data collected were analyzed based on the formula proposed by Bungin [15] in order to find out the students expectation. The formula as follow :

$$
\begin{aligned}
& \mathrm{N} \quad=\frac{F x}{n} \times 100 \% \\
& \mathrm{~N}=\text { The expectation percentage } \\
& F x \quad=\text { Number of frequency } \\
& n \quad=\text { Number of students as sample } \\
& 100 \%=\text { Constant Numeral }
\end{aligned}
$$

The result of percentage show the students perception and attitude toward online learning for English speaking skills. Thus, the percentage of students expectation for each category of five-likert scale is gotten.

\section{RESULTS AND DISCUSSIONS}

The data of the research were from the questionnaire of students' expectation of online learning for English speaking skill that consist of 40 statements. The questionnaires were divided into four parts based on the aspect, they are instructor, interaction, learning style and learning platform. The questionnaires were distributed to 30 English undergraduate students who were taking Oarcy in Academic course. Below are the table of percentage of each category for all of aspects (instructor, interaction learning style and learning platform).

Table 1. Percentage of students' expectation

\begin{tabular}{lllllll}
\hline \multirow{2}{*}{ No. } & Aspect & \multicolumn{2}{l}{ Category } \\
\cline { 3 - 6 } & & $\mathrm{SA}$ & $\mathrm{A}$ & $\mathrm{N}$ & $\mathrm{D}$ & $\mathrm{SD}$ \\
\hline 1. & Instructor & $33 \%$ & $54 \%$ & $12 \%$ & $1 \%$ & $0 \%$ \\
\hline 2. & Interaction & $26 \%$ & $52 \%$ & $17 \%$ & $5 \%$ & $0 \%$ \\
\hline 3 & $\begin{array}{l}\text { Learning } \\
\text { Style }\end{array}$ & $24 \%$ & $51 \%$ & $23 \%$ & $2 \%$ & $0 \%$ \\
\hline 4. & $\begin{array}{l}\text { Learning } \\
\text { Platform }\end{array}$ & $23 \%$ & $53 \%$ & $22 \%$ & $2 \%$ & $0 \%$ \\
\hline & Mean & $27 \%$ & $52 \%$ & $18 \%$ & $3 \%$ & $0 \%$ \\
\hline
\end{tabular}

The table show the percentage of five-likert scale for four aspect. It can seen that the students have positive expectation toward those all of the aspect because the percentage ranging from 50\%. The instructor aspects has the highest percentage with $54 \%$ while learning style has the lowest percentage with $51 \%$. The mean of category agree is $52 \%$, means all of students have positive perception. So it can be concluded that all of the students have high expectation toward all of four aspects. The following are the explanation of each aspects as follow:

a. Instructor

The first data is students expectation of instructor aspect in online learning for English speaking skill. Based on the data above, not all of students have positive perception toward instcutor aspects. Some have neutral and disagree perception. The percentage of students with strongly agree perception are $33 \%$ and with agree perception are $54 \%$. Then, there are $12 \%$ of 
the students are categorized into neutral response. While the rest percentage $1 \%$ belongs to disagree response. Among the four perception, majority of the students have positive perception. Based on these result, it can be said that 30 undergraudate English students have high expectation oward online learning for English speaking skills.

Most of student have high expectation on the all statement in the instructor aspect. However, most of students expect much for statement number 1,3, 4 and 6 . The statement are explain about the expectation for the instructor that do not only act as facilitator of learning but also as motivator for the students. Also the student expect the instructor can be available or easy to communicate when they have questions. Moreover, the students also expect the instructor can give feedback or comment for further discussion. Also give suggestion or advice to their speaking skill. So they can know their weaknesess and know what needs to improved. While for the lowest expectation is learning in group or coopearte with other students. The student have less expectation for learning in group because they can not discuss face-to-face with their groupmate. They need to discuss in group but have to work by themself because they do not meet physically like traditional classroom. This finding similar with Paechter [11] which found the student expect the instructor aspect like giving students advice, support, motivation are important for knowledge building and influence to the course satisfaction and their achievement.

\section{b. Interaction}

The second data is explain the percentage for students expectation of online learning for english speaking skill in the aspect of interaction. The percentage for strongly agree is $26 \%$, for agree is $52 \%$, for neutral is $17 \%$ and the rest $5 \%$ for disagree. So it can be concluded that students also have high expectation for interaction aspects with $52 \%$.

Statement number 4 and 10 are the most expectation that students want. It is about the expectation for the instructor can create discussion atmosphere where the students can share their ideas or comment for the topic or material. Also expect the lecturer and students can discuss together about the students difficulties during online learning. So the learning activities can be active and run well eventhough virtually. While the lowest expectation is online learning can give students opportunities to interact with instructor. However, the students still wants to interact with the instructor but due to the learning virtually, the problem of the signal might be the reason for lowest expectation.

\section{c. Learning style}

The third data is explain the detail percentage for students expectation of online learning for english speaking skill in the aspect of learning style. The percentage for strongly agree is $24 \%$, for agree is $51 \%$, for neutral is $23 \%$ and the rest $2 \%$ for disagree.

The most expectation are for statement number 6, 7 and 8. The statement is focus on developing students English speaking skill with emphasize on how to use facial expression, gesture, tone in speaking and how to respond an uttetance. The students also have high expectation on the use of additional video or audio from online application like Youtube, so it can attract the students' interest to share ideas or give comment. While the lowest expectation for this aspects is for statement 3 about divided the students into group for having discussion. Some students cannot define their expectation or categorized to neutral for having group discussion in the learning process. However, they prefer divided video conferencing into some groups. So they can be brave and do not shy to share their ideas or comment because each group only consist of 5 or 6 students.

\section{d. Learning platform}

The fourth or last data is the percentage for students expectation of online learning for english speaking skill in the aspect of learning platform. The percentage of strongly agree is $23 \%$, for agree is $53 \%$, for neutral is $22 \%$ and the rest $2 \%$ for disagree.

Among 10 statements, the most expectation is for statement number 4, 6 and 9. The statement is about the use of additional platform or social media beside learning application. The platform or social media like Youtube and Instagram can attract the students interest and motivate them to practice speaking. Moreover, the students also have high expectation for the use of learning platform that can give choices related to time, place and the regulation of learning process. Also the most expectation is the online learning media can be functional that do not only provide course material but also easy to create discussion for practice speaking.

Related to the learning process of Oracy in Academic Context course, the instructor already use various learning application and additional platform or social media in order to maxime the online learning for speaking and can arrouse students interest. From these

\section{CONCLUSION}

Based on the findings above, it can be concluded that English undergraduate students who were taking Oracy in Academic course have high expectation toward the four aspects (instructor, interaction learning style 
and learning platform) in online learning for English speaking skill. The ranging from the highest expectation until the lowest is instructor, learning platform, interaction and learning style. Eventhough the lowest expectation is learning styles but it does not make learning style not being paid attention during online learning. The student emphasizes more on the instructor aspects because the instructor is the one who know the student, choose the learning style and learning platform. So, as long as the instructor competent in teaching, the other aspect in online learning can be handled.

\section{ACKNOWLEDGMENT}

First of all, I would like to express sincere gratitude to Allah SWT and the prophet Muhammad SAW for the blessing and all, so I could finish the paper entitled 'English undergraduate students' expectation of online learning for English speaking skill". I also would like to thank to the English education study progma. Last but not least, sincere gratitude for Dr. Hamzah, MA, MM as my supervisor who has given a lot of guidance and advice such as suggestion, correction, opinion and idea that are very useful in the process of finisihing this paper. Overall, I realize this paper far from being perfect. So, any suggestion, idea, comment, or critic that are useful in improving this paper are welcomed.

\section{REFERENCES}

[1] C. Cavanaugh and T. Clark, "The Landscape of K12 Online Learning", in What Works in K-12 Online Learning, C. Cavanaugh, R. Blomeyer and S. Patrick, United States of America: International Society for Technology in Education (ISTE), 2007, pp. 5-20

[2] R. Rose and A. Smith. "Online Disscusions", in What Works in K-12 Online Learning, C. Cavanaugh, R. Blomeyer and S. Patrick, United States of America: International Society for Technology in Education (ISTE), 2007, pp. 143160.

[3] M. Ally. "Foundations of educational theory for online learning", in The Theory and Practice of Online Learning, T. Anderson, Canada: AU Press, 2004, pp.15-44.

[4] K. Mounika and S. Thamarana. Teaching Speaking Skills Online: Prospects and Possibilities. Presented at 6th annual international conference, 2018.

[5] D. U. Bolliger and C. Halupa. Student perceptions of satisfaction and anxiety in an online doctoral program. Distance Education, vol. 33, no. 1, pp.
81-98 ～2012. http://dx.doi. org/10.1080/01587919.2012.667961.

[6] C. Shao. An empirical study on the identification of driving factors of satisfaction with online learning based on tam. Advances in Economics, Business and Management Research, vol 110, pp. 1067-1073, 2019.

[7] J. Wu, R. D Tennyson and T. Hsia . A study of student satisfaction in a blended e-learning system environment. Computers \& Education. vol 55. pp. 155-164, 2010. doi:10.1016/ j.compe du. 2009.12.012.

[8] M. B. Pinto and W. Anderson. Little knowledge goes a long way Student expectation and satisfaction with hybrid learning. Journal of Instructional Pedagogies, 2013.

[9] S. Lemos and N. Pedro. Students' expectation and satisfaction in post-graduate online courses, pp. 568-580, 2012

[10] D. U. Bolliger and T. Martindale. Key factors for determining student satisfaction in online courses, International Journal on E-Learning, pp. 61-67, 2004.

[11] M. Paechter, B. Maier and D. Maehter. Students' expectations of, and experiences in e-learning: Their relation to learning achievements and course satisfaction. Computeters \& Education, pp. 222229, 2010.

[12] H. Wei and C. Chou. Online learning performance and satisfaction: do perceptions and readiness matter?, Distance Education, 2020. doi: 10.1080/01587919.2020.1724768

[13] Cole, M., T., Shelley, D., J. and Swartz, L. B. Online instruction, e-learning, and student satisfaction: a three year study, vol. 15 , no 6 , pp. 111-131, 2014

[14] D. Shaw, Y. S. S. Tham, J. Hogle \& J. Koch Desire: a key factor fo $r$ successful online ged adult learners. Journal of Research and Practice for Adult Literacy, Secondary, and Basic Education, vol. 4, no. 1, pp. 21-36, 2015.

[15] B. Bungin. Metode penelitian kuantitatif. Jakarta: Kencana Prenada Media Grup, 2006. 